\title{
Study on the Influence Mechanism of Monetary Policy on Real Estate Price Regulation
}

\author{
Hailin Wang \\ Rizhao Polytechnic, Liaocheng Street, Rizhao, China \\ rzwang2007@126.com
}

Keywords: real estate prices; monetary policy; machine-processed

\begin{abstract}
Real estate prices in China have been rising since 1998, and in the short term, the phenomenon of price increasing fast is constantly appearing. Accordingly, our country has adopted a lot of macro-control policies to deal with the excessive rise in real estate prices. Monetary policy is an important means of national macro-control, which can play a role in regulating real estate prices. The study of the influence mechanism of monetary policy on real estate price regulation is of great significance to stabilize house price and promote the steady development of economy.
\end{abstract}

\section{Reasons for the Rise in Real Estate Prices in Recent Years}

Since1998, with the withdrawal of welfare housing system, the continuous expansion of urban land resources, the price of urban real estate in China has been increasing year by year. The main reasons for the price increase are as follows:

\subsection{Lack of welfare housing system}

Since the founding of the people's Republic of China, our country has been carrying out the welfare housing division system, that is, the residents' housing is transferred to the unit land by the state, and the units build their own residential houses and distribute them to the unit workers according to certain rules. Under the welfare division system, housing only plays the role of basic living security of residents which has not been transferred, there is no necessity of buying and selling, and has the characteristics of "big pot rice". Since 1988, the state has stopped implementing the welfare housing division system, and began to implement the housing trading system, housing can be freely transferred in the market, rented and so on, real estate developers have emerged. Housing supply is mainly provided by real estate providers, urban residents are the main demand side of real estate. The price of housing depends on the supply and demand of housing, and the supply of housing is mainly determined by real estate developers. When the land cost of real estate developers is higher, housing prices are relatively higher. With the reform and opening-up, land prices continue to increase, which directly led to the rise in housing prices. 


\subsection{Limited urban land resources}

In the process of reform and opening up, our country has changed the original extensive growth mode, implemented intensive and urbanization development strategy, in the process of development, the scale of cities has been continuously expanded, and the land area available for urban use has been continuously reduced. Urban land shows the characteristics of scarcity. Although the city continues to spread to the periphery, but the urban land stock is still limited, the state adopts the urban land planning policy of "asking for space from the stock" to improve the existing land utilization ratio. In the short term, this policy is effective. However, in the long run, urban land resources are still limited, and the space of "asking for space from stock" is also limited. The limitation of land resources causes the rise of land price, and the rising of land price leads to the rise of the cost of real estate opening agent, which leads to the rising of house price.

\subsection{The expanding scale of urban population}

Since the reform and opening up, with the expansion of urbanization process, the scale of urban population continues to grow. The demographic dividend brought by urban population growth has led to an ever - increasing demand for housing in the city. According to Wan De, From 2009 to 2014, eight of the top 10 cities in the list also ranked among the top 10 in terms of population growth, which illustrating the positive relationship between urban population size and rising housing prices. Although the state has begun to take restrictions on the household registration system in first line cities such as Beijing, Guangzhou and Shenzhen, the growth rate of population in the first tier cities is still growing. For the second, third and fourth tier cities, their population size is similar to the first-tier cities, showing an upward trend year by year, but the growth rate is fast or slow. With the expansion of urban population, the demand for housing is also expanding year by year, but the limited urban land resources lead to the limited housing, the demand is greater than the supply, so the housing price is rising.

\section{The Relationship between Monetary Policy and Real Estate Price}

In order to further explore the effective means of regulating real estate prices, after in-depth analysis of the reasons for the rise in real estate prices, we further analyze the relevance between monetary policy and real estate prices mainly from three aspects: interest rate instruments, bank deposit rate, bank real estate credit.

\subsection{Interest rate instrument and Real Estate Price}

Interest rate instrument is an important aspect of monetary policy in China. Interest rate instrument has the characteristics of easy observation, stability and maneuverability, and it is often used by the central bank as a means of monetary regulation and control. At present, the interest rate of our country is still controlled by central bank and has not been marketized. Generally, the central bank gives the benchmark interest rate, and the actual interest rate is floating or lowering a certain percentage on the basis of the benchmark interest rate. Since 1996, China has gradually proposed the reform of interest rate marketization and the adjustment of the monetary benchmark interest rate for different periods. Changes and adjustments in benchmark interest rates are generally associated with real estate prices just as follows:

Interest rates fell from 1996 to 2003 when house prices rose. The benchmark interest rate on bank loans fell from 13.14 percent to 5.49 percent, and house prices rose from 2052 RMB per square meter to $2359 \mathrm{RMB}$ per square meter. It can be seen that with the decline of interest rates, 
house prices continue to rise, and there is a significant negative correlation between interest rates and house prices.

From 2004 to 2007, both interest rates and house prices rose. At this stage, the bank loan benchmark rate increased from 6.12 percent to 7.83 percent, while the house price rose from 2714 RMB per square meter to 3864 RMB per square meter. Housing prices and interest rates show a synchronous upward trend, showing a positive correlation.

In 2008, interest rates and house prices both fell. At this stage, the financial crisis broke out, and the global economic situation was grim. The state cut interest rates to stimulate the economy, from 7.83 percent to 5.94percent, and house prices fell from 3864 RMB per square meter to $3799 \mathrm{RMB}$ per square meter. It can be seen that as interest rates fall, house prices also fall, and there is a positive correlation between interest rates and house prices.

Between 2009 and 2011, interest rates and house prices rose simultaneously. At this stage, the benchmark interest rate on bank loans increased to 7.05 RMB and house prices increased to 5357 RMB per square meter. As you can see, as interest rates rise, house prices also rise, interest rates and house prices show a positive correlation.

The period that interest rates have fallen and house prices have risen since 2012. This stage, the country carries out the interest rate marketization reform, reduces the interest rate unceasingly, but as soon as the house price has been rising, there is a significant negative correlation between interest rate and house price.

From the above analysis, we can see that there is a certain relationship between interest rate and house price, but the relationship between them is not clear, sometimes positive correlation, sometimes negative correlation. Therefore, the interest rate can be used to regulate house prices, which will have certain effect but the regulatory effect has certain uncertainty.

\subsection{Bank deposit rate and real estate price}

The bank deposit rate refers to the proportion of deposit reserve amount required by the central bank to the total deposit amount of the financial institution. It is another important means of monetary policy and has the characteristics of flexibility, correctability and maneuverability. Bank deposit rates are more flexible and operational than interest rate instruments, and the central bank can operate them frequently. There is a certain correlation between bank deposit rate and real estate price, mainly as follows:

July 2006 to June 2008, to raise the level of bank deposit registration. In this stage, China's economy is growing rapidly, investment is overheating and inflation appears. In order to effectively restrain investment overheating and inflation, the central bank has continuously raised the bank deposit rate, which rose from 7.5 percent in 2006 to 17.5 percent in 2008.At this stage, house prices are rising, and there is a significant positive correlation between house prices and bank deposit rate.

July 2008 to December 2008, the phase of rating down bank deposit. In this stage, the financial crisis broke out. In order to promote the economy to pass the financial crisis smoothly, the central bank continuously lowered the bank deposit rate to ensure real economic liquidity, the large financial institution deposit rate was lowered to 15.5, and the small financial institution deposit rate was lowered to 13.5. However, the real estate price in this stage is warming up after a small correction, and the relationship between bank deposit rate and real estate price is uncertain.

January 2009 to June 2011, the stage of rating up the bank deposit. During this period, the financial crisis slowly passed, but as the implementation of loose monetary policy led to a phenomenon of excess liquidity, the central bank began to gradually raise the bank deposit rate. The deposit rate of large financial institutions rose to 21.5, and that of small banks rose to 18, reaching an all-time level. And this stage of real estate prices are also rising, but the rate of increase slowed 
down. This shows that the bank deposit rate and real estate prices show a significant positive correlation.

Since July 2011, the bank deposit rate has declined. In this stage, the economy of our country runs smoothly and effectively, showing the pattern of "steady growth and adjusting structure". In order to hedge against the effects, the central bank lowered the reserve rate of banks to 16.5 for large financial institutions and 13 for small financial institutions. Although the real estate price in this stage shows a continuous rising trend, the rising speed is obviously slower, which indicates that the bank deposit rate and real estate price have a negative correlation, but not obvious.

It can be seen from the above analysis that there is a certain correlation between bank registration rate and real estate price, but because of the economic situation and so on , the relationship between them is not clear. Therefore, when the bank registration rate is adopted as the control means to control real estate price, it will have certain effect but the effect is equally uncertain .

\subsection{Real estate credit and real estate prices.}

Real estate credit refers to the long-term and short-term loan policies of financial institutions related to real estate development and sales. On the one hand, from the angle of real estate developers, with the increase of land cost, real estate developers do not have enough funds to buy land, and they need to obtain loans through financial institutions. Loans for real estate developers have both short-term and long-term loans. On the other hand, from the consumer's point of view, the consumer has a demand for buying housing, but the house price is rising continuously, the consumer's income is limited, it is very difficult to pay off the house in full at one time, the ordinary consumer buys the house through the way of long-term loan from the bank. It can be seen that the bank acts as the intermediate link of real estate development and sales, and provides two-way capital support for both supply and demand of real estate development. Therefore, the bank real estate credit interest rate and real estate prices will have a certain correlation.

The total amount of bank real estate loans consists of two parts, one is the amount of real estate loans and the other is the amount of residential loans. According to statistics, the bank real estate loan balance has been rising year by year since 2003, and the housing price also has the overall upward trend in this stage, only appeared "stagflation" in the financial crisis stage of 2008.This shows that there is a significant positive correlation between real estate loans and housing prices. Real estate credit can be used as an effective method to control real estate prices.

It can be seen that interest rate, bank deposit and loan rate, real estate credit are all related to real estate price, which can be used to control the real estate price effectively in combination with the economic situation.

\section{Analysis of the Influence Mechanism of Monetary Policy on Real Estate Price Regulation}

On the basis of in-depth analysis of the reasons for the sustained rise in real estate prices, as well as the relevance between interest rate instruments, bank deposit rates, real estate credit and real estate prices, monetary policy can be used as an effective means to control real estate prices. This part further probes into the operation mechanism of monetary policy to real estate price regulation, and analyzes the details as follows:

From the above analysis, we can see that there is a significant positive relationship between bank real estate credit and house price, and there is a correlation between bank interest rate and bank deposit rate and house price, but the relationship is not clear. At the same time, because the bank deposit rate is actually by adjusting the supply of bank credit funds to affect the demand of home buyers, and then regulate the housing prices. Bank real estate credit also affects the demand for 
housing and house prices by adjusting the money supply of bank credit funds. It can be seen that bank deposit rate and bank real estate credit have a simple and direct impact on real estate price control. Therefore, this paper focuses on the impact mechanism of bank interest rate tools on real estate price regulation, mainly from the cash flow discount model, capital asset pricing model and supply and demand balance model three angles, the details are as follows:

\subsection{Cash flow discount model}

The discounted cash flow model is a commonly method to evaluate the asset price. Its basic principle is that the present value of the asset is equal to the cumulative value of its future expected income according to the discount rate, in which the discount rate is generally expressed as the interest rate. Therefore, we can use the discounted cash flow model to study the mechanism of bank interest rate instruments on real estate price regulation. Under the cash flow discount model, the real estate price is the present value. The future income of the real estate mainly includes the real estate rent income and the future sale real estate income, the discount rate is the bank interest rate. After knowing the future rental income and the one-time income from the sale of real estate, the bank interest rate can be used to calculate the present value of the real estate, that is, the real estate price. Therefore, from the view of the model, the government can not change the future real estate sale income and real estate rental income, the government can change the bank interest rate, by changing the bank interest rate to achieve the regulation of real estate prices. When the government raises the interest rate of the bank, under the condition that the future rent income and the one-off income of selling the real estate will not change, the accumulated discount value of the whole income of the real estate will decrease, and the present value of the real estate (the real estate price) will fall; When the government lowers bank interest rates, the cumulative discounted value of all future earnings will increase and the present value of real estate (real estate prices) will rise, with future rental income and one-off income from the sale of real estate unchanged. Therefore, monetary policy can achieve real estate price regulation to some extent through cash flow model.

\subsection{Capital assets pricing model}

The capital asset pricing model holds that the expected return of risk assets is equal to the level of non - risk income plus the income level of risk compensation. The expected yield of risk assets is equal to the market ' $\mathrm{s}$ riskless interest rate plus the risk compensation rate. Therefore, we can use the capital asset pricing model to control the real estate price by monetary policy, and it can be considered that the expected yield of real estate is equal to the market ' s riskless interest rate (bank interest rate) plus the risk compensation rate. When the expected rate of return of real estate is much higher than the risk-free interest rate of the market, the risk compensation rate of real estate is higher, and the real risk of residents buying housing is lower. As a result, residents tend to buy houses, which in turn contribute to higher real estate prices When the expected rate of return on real estate is much lower than the market's risk-free interest rate, the risk compensation rate for real estate is negative, and the real risk of residents buying a house is very high, so residents tend to give up buying houses. In turn, promote the decline in real estate prices. In the whole process, the riskfree interest rate of the market is the interest rate of the bank. The government cannot change the expected rate of return and the risk compensation rate of the real estate. The government has achieved real estate price control by changing bank interest rates. Therefore, monetary policy can control the real estate price to some extent through the capital asset pricing model. 


\subsection{Supply-demand equilibrium model}

The equilibrium model of supply and demand refers to the effect of monetary policy on real estate price regulation from the two aspects of real estate supply and demand. The analysis is as follows:

From the real estate demand side, monetary policy can achieve the regulation of real estate prices. The main principle is as follows: the demand side of real estate, that is to say, buy a house, from the current point of view, China's buyers (real estate demand-side) are basically through the way of bank loans to buy housing, that is, a certain proportion of the down payment, the remaining price installment payment. If the bank raises interest rates, then the amount of debt service will increase for buyers, the cost of buying a house will increase, and buyers may give up buying houses, when the interest rate is up to a certain level. As the number of people giving up buying more and more, demand for real estate falls. In the case of constant supply in the real estate market, according to the theory of balance of supply and demand, real estate prices will fall. In the same way, if banks cut interest rates, then the amount of debt service will be reduced for buyers, the cost of buying a house will be reduced, and buyers will be more interested and able to buy houses, when the interest rate is as low as a certain degree. An increasing number of people are interested in buying homes, that is, rising demand for real estate. And in the real estate market supply unchanged, according to the theory of balance between supply and demand, real estate prices will rise. Therefore, the market demand of real estate is negatively related to interest rate, and monetary policy can control the real estate price.

From the real estate supply side, monetary policy can achieve the regulation of real estate prices. The main rationale is as follows: the supply side of real estate, that is, real estate developers, for them, the development of a real estate project needs a huge amount of money, free capital and shareholder investment is generally unable to meet the needs of development projects. Need bank loan, bank interest is also an important part of the cost of real estate developers. If the interest rate of the bank is raised, then the amount of debt service paid by the real estate developer will increase, the cost of the real estate developer will increase, and the project investment income of the real estate developer will decline. When the bank interest rate is raised to a certain extent, and the investment income of real estate developers is decreasing, the real estate opening chamber has given up investing in real estate development, which has led to a drop in the supply of housing in the market. With demand for housing unchanged, real estate prices rise as supply declines. Similarly, if bank interest rates are lower, for real estate developers, the amount of monthly debt service is lower, the cost of real estate developers is lower, and other conditions remain unchanged, real estate developers' investment returns will increase. When bank interest rates continue to fall, real estate developers' investment returns continue to rise, which will stimulate real estate developers to increase their investment and the supply of real estate in the market will rise. With demand for housing unchanged, real estate prices fall as supply rises. Therefore, the market supply of real estate is negatively related to interest rate, and monetary policy can control the real estate price to a certain extent.

From the above analysis we can see, whether it is considered from the demand of real estate, or from the real estate supply, changes in interest rates will bring the real estate supply and demand. According to the equilibrium theory of supply and demand, the real estate market price is determined by the supply and demand of real estate, when demand the amount and the quantity supplied is equal, will achieve the market equilibrium. The government through the change of bank interest rates, thereby changing the supply of real estate and real estate demand, demand and supply curves in real estate have changed, the real estate supply and demand balance changes, and ultimately affect the market price of real estate. Therefore, the government can change the bank 
interest rates, the market demand curve and the supply curve and the change of the real estate market, realize the regulation of real estate prices, the government can through the supply and demand balance model to achieve Regulation of real estate price.

\section{Conclusion and inspiration}

Since the reform and opening up, with the withdrawal of welfare housing system, the rarity of urban land resources and the continuous expansion of urban population, the real estate market price in China has been rising year by year. Through the data analysis, we can get that the bank interest rate, the bank deposit rate and the bank credit have certain correlation with the real estate price. On this basis, this paper further uses the discounted cash volume model, the capital asset pricing model and the supply-demand equilibrium model to analyze the influence mechanism and path of monetary policy on real estate price regulation. This paper holds that the government can control the excessive rise of real estate price effectively by using monetary policy tools to control the real estate price. Specifically, the government should, on the one hand, promote the reform of marketization of interest rates and relax the control of interest rates, which is conducive to promoting the level of interest rates to truly reflect the demand and supply situation of the market, and to increase the flexibility of interest rates. Then the interest rate can play a guiding role for the real estate developers and buyers. Through the discounted cash flow model, the capital asset pricing model and the supply-demand equilibrium model, the real estate price can be effectively regulated. On the other hand, the bank deposit reserve system should be reformed, mainly to relax the bank reserve requirement ratio and to reduce the bank deposit reserve as far as possible, so that the burden of the central bank can be effectively reduced. It can also enhance the flexibility and efficiency of interest rate adjustment, and improve the effectiveness of monetary policy. Third, it is necessary to continuously improve the bank credit policy. Bank credit interest rates and terms will have an important impact on real estate prices. Bank credit interest rates and terms should be adjusted rationally according to the specific supply and demand situation in the real estate market. In order to achieve effective control of real estate prices.

\section{References}

[1] Gu Haifeng, Zhang Yuanjiao. Monetary Policy and Real Estate Price Regulation: theory and Chinese experience [J]. S 1: 29-43.

[2] Xu Jiyi.A study of Real Estate Price Regulation in China from the Perspective of Financial Ecology [J]. Enterprise economy 022: 141-144.

[3] Wang Liang, Meng Congling. A review of China 's real estate price adjustment and control policy from the five new countries. Price Monthly, 2013, 06: 4 - 7.

[4] Gao Dongsheng. Dilemmas and Solutions in Real Estate Price Regulation in China [J]. Economic problems: 09: 34-37.

[5] Wang Zeyu.An empirical Analysis of the effect of the New deal on Real Estate Price Regulation-based on the microcosmic data of Beijing and Tianjin [J]. Exploration of economic problems 2014: 04: 168-173.

[6] Yu Yao, Chu Yijiang.Study on the Policy of Real Estate Price Control-Analysis of the Regulation Policy under the High Price of Commodity Housing in recent years [J]. Price Theory and practice 2009 10: 41-42.

[7] The practice and thinking of Nanjing Real Estate Price Regulation and Control [J]. Price Theory and practice 2008 01: $20-21$.

[8] Wang Jianhui.The Dilemma and Countermeasures of China's Real Estate Market Regulation-from the Perspective of Real Estate Price Regulation [J]. Journal of Graduate School of Central South University of Finance, Economics and Law.

[9] Chang Qing, Shi Yu.According to the price formation theory to improve the real estate price regulation [J].Price Theory and practice 2007 08: 38.

[10] He Yunxin.Real estate price control: is to curb the rate of rise or control the level of value [J].The monthly price is in 2005 / 07: 28. 
[11] FanLili.A study on the influencing factors of Real Estate Price change in China based on Regional differences [D]. Agricultural University of China.

[12] Li Yumei.An empirical study on the characteristics and influencing factors of Real Estate Price in China [D]. Jilin University.

[13] Sa Qiurong.A study on the relationship between Real Estate Price fluctuation and Bank Credit [D].Nankai University.

[14] Yuan Pengfei.General equilibrium Analysis of the impact of Real Estate Price fluctuation on Macroeconomics [D]. Xiamen University.

[15] Duan Zhongdong.Real estate prices and monetary policy [D]. Hunan University. 